\title{
Association between $\delta$-aminolevulinate dehydratase G177C polymorphism and blood lead levels in brain tumor patients
}

\author{
MAHMOUD MOSTAFA TAHA ${ }^{1}$, OSAMA ABD EL AZIZ GABER ${ }^{2}$, \\ NORHAN ABDALLA SABBAH ${ }^{2}$ and ABD ALLAH S ABD ELAZEM ${ }^{3}$
}

Departments of ${ }^{1}$ Neurosurgery and ${ }^{2}$ Medical Biochemistry, Faculty of Medicine, Zagazig University, Zagazig 44512; ${ }^{3}$ Department of Medical Biochemistry, Faculty of Medicine, Al-Azhar University, Assiut 71511, Egypt

Received February 13, 2015; Accepted June 15, 2015

DOI: $10.3892 / \mathrm{mco} .2015 .589$

\begin{abstract}
As the $\delta$-aminolevulinic acid dehydratase $(A L A D)$ G177C polymorphism affects the toxicokinetics of lead in the body, and the corresponding exposure to lead may increase the risk of adult brain tumors, we hypothesize that there is a possible association of the $A L A D$ G177C genotype and the risk of brain tumors in human. Therefore, the aim of the present study was to clarify the role of the ALAD enzyme gene polymorphism at position $\mathrm{G} 177 \mathrm{C}$ in the pathogenesis of brain tumors and its correlation to lead exposure. The $A L A D$ gene polymorphism at position G177C was genotyped using the polymerase chain reaction with restriction fragment length polymorphism method and measured the blood lead level by atomic absorption in 81 brain tumor patients and compared the results with 81 controls. The frequency of the GC genotype ( $A L A D 1-2)$ was significantly increased in primary brain tumor patients compared to the control group. The genotype frequency of ALAD2 (ALAD1-2 and ALAD2-2) was significantly higher in the meningioma patients but was not significant in glioma patients. There was no significant difference in the number of patients and blood lead level when compared with the control. There was a significant increase when compared to $A L A D 1$ regarding a mean value of the lead level. The genotyping of the $A L A D$ G177C polymorphism in the present study revealed a significant association between $A L A D 2$ and brain tumors. The $A L A D G 177 C$ polymorphism may modify the lead kinetics in the blood, is associated with higher blood lead burden and may provide a biomarker of neurotoxic risk.
\end{abstract}

Correspondence to: Professor Mahmoud Mostafa Taha, Department of Neurosurgery, Faculty of Medicine, Zagazig University, Belbis-Zagazig Road, Zagazig 44512, Egypt

E-mail: mahmoudlotfy1972@yahoo.co.uk

Key words: brain tumor, lead, $\delta$-aminolevulinic acid dehydratase gene, polymorphism, meningioma

\section{Introduction}

Community and occupational exposures of adults to lead has been recognized for centuries, particularly in Egypt, as unfavorable effects on the hematopoietic, gastrointestinal, urinary, cardiovascular and nervous systems have been well-documented (1). The International Agency Research on Cancer recently reclassified inorganic lead to a 'probable' human carcinogen due to evidence from animal carcinogenicity and limited human carcinogenicity (2). Whereas certain epidemiological studies have reported an increased risk of brain tumors with potential lead exposure (3), particularly meningioma $(4,5)$, another study has reported no significant association between lead and brain cancer (6).

Increasing attention has focused on interpreting the genetic factors that elucidate the differences in symptoms between individuals who have had similar lead exposures. Identification of such genes would aid in the explanation of variation in the association between biological markers of lead exposure and measures of organ dysfunction.

The $\delta$-aminolevulinic acid dehydratase $(A L A D)$ gene codes for the enzyme ALAD that catalyzes the second step of heme synthesis in which two molecules of ALA condense to form porphobilinogen. The most commonly known polymorphism in the gene, ALAD G177C (dbSNP ID: rs1800435) contains a G-to- $C$ transversion at position 177 of the coding region, resulting in the substitution of asparagine for lysine. $A L A D$ G177C has two co-dominant alleles: $A L A D 1$ and ALAD2 (7).

ALAD can be inhibited by various chemicals, including lead, trichloroethylene, bromobenzene and styrene (8), however, the polymorphic differences in enzyme binding or chemical uptake are more comprehensive for lead. Individuals with the $A L A D 2$ allele have been shown to exhibit higher blood lead levels compared with the ALADI homozygotes, possibly due to tighter binding of lead by the ALAD2 enzyme (9).

How the $A L A D$ genotype influences the distribution of lead to target organs remains unknown. However, it has been documented that the binding of lead molecules inactivates $\delta$-ALAD and causes a rise in the levels of its substrate, $\delta$-ALA ( $\delta$-ALA) (10). In the brain, excess $\delta$-ALA disrupts the $\gamma$-aminobutyric acid/glutamate system in several ways, creating potential for neuroexcitotoxic events and cell death (11). 
Previous studies have indicated that ALAD2 may be protective against the neurotoxic/neurobehavioral effects of lead $(12,13)$. However, it has also been observed that ALAD2 may confer an increased risk of meningioma (14).

The possible genetic susceptibility and the potential association between lead and brain tumor risk have not been previously evaluated in the Egypt population. The aim of the present study was to examine the associations between the $A L A D$ G177C polymorphism and blood lead burden in adult brain tumor Egyptian patients.

\section{Materials and methods}

The present study included 81 patients with brain tumors and 81 gender- and age-matched healthy control subjects. The study was carried out in Departments of Neurosurgery and Medical Biochemistry, Faculty of Medicine, Zagazig University (Zagazig, Egypt).

Participants. The patient group included 81 patients with brain tumors with surgery performed in the Department of Neurosurgery and confirmed by histopathology. The ages of the patients were $>18$ years old. Only patients with primary brain tumors were included. Patients were excluded if they had secondary brain tumors or they were $<18$ years old.

The control group included 81 gender- and age matched subjects to the patients. They were selected randomly from the same population as the patients, and were collected from cases admitted in the Department of Neurosurgery for a variety of non-neoplastic conditions.

All the participants were recruited from Zagazig University Hospital and Department of Neurosurgery. All the subjects were of Egyptian nationality. Written informed consent was signed by all the participants. The study design was approved by the Ethics Committee of Faculty of Medicine, Zagazig University.

All the participants were subjected to: i) History; demographic data were collected from the patients in the form of age, gender and any systemic disorder, past history of systemic treatment. ii) Examination; all subjects underwent complete neurological examination. iii) Radiological investigations by computed tomography and magnetic resonance imaging (MRI); post-operative histopathology to detect the type of the brain tumor for the patients.

DNA extraction. DNA was isolated and purified from whole blood (EDTA) using the manufacturer's instructions (Qiagen $\mathrm{GmbH}$, Hilden, Germany). The purified DNA was stored at $-20^{\circ} \mathrm{C}$ for later use.

Genotyping of ALAD G177C gene polymorphism. A polymerase chain reaction with restriction fragment length polymorphism (PCR-RFLP) assay was used for detection of the $A L A D$ G177C (rs 1800435) polymorphism, as described by Lee et al (15), using the following primers: Forward, 5'-AGA CAG ACA TTA GCT CAG TA-3' and reverse primers, 5'-GGC AAA GAC CAC GTC CAT TC-3'.

PCR was carried out in a final volume of $50 \mu \mathrm{l}$ containing $100 \mathrm{ng}$ of template DNA $(5 \mu \mathrm{l}), 1.0 \mu \mathrm{M}$ of each primer (1 $\mu \mathrm{l})$ (MBI Fermentas GMBH, St. Leon-Rot, Germany),
$25 \mu \mathrm{l}$ of $2 \mathrm{X} \mathrm{I-Taq}{ }^{\mathrm{TM}}$ PCR Master mix (Intron Biotechnology, Gyeonggi-do, South Korea) and $18 \mu \mathrm{l}$ deionized water.

Cycling conditions were initial denaturation of $94^{\circ} \mathrm{C}$ for $10 \mathrm{~min}$, followed by 32 cycles of $94^{\circ} \mathrm{C}$ for $30 \mathrm{sec}, 55^{\circ} \mathrm{C}$ for $30 \mathrm{sec}$ and $72^{\circ} \mathrm{C}$ for $1 \mathrm{~min}$, and finally $72^{\circ} \mathrm{C}$ for $7 \mathrm{~min}$ using DNA Thermal Cycler 480 (serial no, P 16462; Perkin-Elmer, Norwalk, CT, USA).

Digestion by restriction enzyme. The digestion of the 916-base pair (bp) $A L A D$ genomic sequence containing the $A L A D 1 / A L A D 2$ polymorphic site was performed using restriction endonuclease $M s p I$ (MBI Fermentas $\mathrm{GmbH}$ ). It was performed in a $25-\mu 1$ volume $(2.5 \mu \mathrm{l} 10 \mathrm{X}$ Buffer, $1 \mu \mathrm{l} 10 \mathrm{U} / \mu \mathrm{l}$ MspI, $15 \mu 1$ PCR product and $6.5 \mu 1$ deionized water).

The samples were incubated at $37^{\circ} \mathrm{C}$ for $1 \mathrm{~h}$. Digestion of the PCR fragments produced one fragment, 582-bp, represented ALAD1-1 genotype. Two fragments, 582 and 511-bp, representing the $A L A D 1-2$ genotype, while one fragment, 511-bp, represented the ALAD2-2 genotype.

Gel electrophoresis detection of ALAD genotype. The digestion products were separated in $2 \%$ agarose using Submarines Gel Electrophoresis System (Pharmacia Biotech by Intertek Semko AB, Kista, Sweden) and submarine chamber (Maxicell, EC360; M-E-C Apparatus Corp., St Petersburg, FL, USA), subsequently visualized with ethidium bromide staining under ultraviolet trans-illumination (Herolab GmbH Laborgerate, Wiesloch, Germany) with the 100-bp SiZer ${ }^{\mathrm{TM}}$ DNA marker (Intron Biotechnology) and photographed.

Atomic absorption spectroscopic measurement of blood lead. Lead was determined directly in whole blood using graphite furnace atomic absorption spectrometry, according to Miller et al (16). Measurement was achieved by atomic absorption using the Buck model 210 VGP atomic absorption spectrophotometer (Buck Scientific Instrument Manufacturing Company AA, East Norwalk, CT, USA) with a graphite furnace option with background correction; the measurement was read at wavelength $283.3 \mathrm{~nm}$ following electro-thermal atomization. The absorption is proportional to lead content and is used to yield quantitative lead content on the basis of comparison with standard series.

Statistical analysis. The results for continuous variables are expressed as mean \pm standard deviation (SD). The means of the groups were compared by the analysis of variance (ANOVA) test. The statistical significances of differences in the frequencies of variants between the groups were tested using the $\chi^{2}$ test. In addition, odds ratios (OR) and $95 \%$ confidence interval (CI) were used. Genotype frequencies in cases and controls were tested for Hardy-Weinberg equilibrium and any deviation between the observed and expected frequencies was tested for significance using the $\chi^{2}$ test. $\mathrm{P}<0.05$ was considered to indicate a statistically significant difference. Data were analyzed using SPSS software version 11 (SPSS, Inc., Chicago, IL, USA).

\section{Results}

Demographic data of patients and controls. There was no significant difference with regards to age $(\mathrm{P}=0.54)$ and 
Table I. Demographic data of primary brain tumor patients versus controls.

\begin{tabular}{lcc}
\hline Parameters & Control group, $\mathrm{n}=81$ & Primary brain tumor patients, $\mathrm{n}=81$ \\
\hline Age, mean years \pm SD (range) & $43.88 \pm 11.68(19-65)$ & $45.09 \pm 13.69(18-67)$ \\
Gender, no. $(\%)$ & $36(44.4)$ & $34(42.0)$ \\
Male & $45(55.6)$ & $47(58.0)$ \\
Female & & $0.54^{\mathrm{a}}$ \\
\hline
\end{tabular}

${ }^{\mathrm{a}}$ Two tailed t-test; ${ }^{\mathrm{b}} \chi^{2}$ test. SD, standard deviation.

Table II. Demographic characteristics of primary brain tumor patients following stratification by the tumor type versus controls.

\begin{tabular}{|c|c|c|c|c|}
\hline Parameters & Glioma, $\mathrm{n}=41(50.6 \%)$ & Meningioma, $\mathrm{n}=31(38.3 \%)$ & Other tumors, $\mathrm{n}=9(11.1 \%)$ & P-value \\
\hline Age, mean years \pm SD & $45.73 \pm 11.59$ & $44.87 \pm 12.00$ & $42.92 \pm 19.98$ & $0.83^{\mathrm{a}}$ \\
\hline \multicolumn{5}{|l|}{ Gender, no. (\%) } \\
\hline Male & $16(39.0)$ & $14(45.2)$ & $4(44.4)$ & $0.86^{\mathrm{b}}$ \\
\hline Female & $25(61.0)$ & $17(54.8)$ & $5(55.6)$ & \\
\hline
\end{tabular}

${ }^{\mathrm{a}}$ Analysis of variacnce test between three tumor types; ${ }^{\mathrm{b}} \chi^{2}$ test. Controls, $\mathrm{n}=81 . \mathrm{SD}$, standard deviation.

Table III. Genotypes and allele frequencies of the ALAD G177C gene in the studied groups.

\begin{tabular}{|c|c|c|c|c|}
\hline$A L A D$ G177C polymorphism & Controls, no. (\%) & Primary brain tumor patients, no. $(\%)$ & OR $(95 \% \mathrm{CI})$ & P-value ${ }^{a}$ \\
\hline \multicolumn{5}{|l|}{ Genotype, } \\
\hline $\mathrm{GG}(A L A D 1-1)$ & $64(79.0)$ & $46(56.8)$ & 1 (Reference) & \\
\hline $\mathrm{GC}(A L A D 1-2)$ & $12(14.8)$ & $23(28.4)$ & $2.28(1.04-4.97)$ & $0.03^{\mathrm{b}}$ \\
\hline $\mathrm{CC}(A L A D 2-2)$ & $5(6.2)$ & $12(14.8)$ & $2.64(0.88-7.88)$ & 0.07 \\
\hline \multicolumn{5}{|l|}{ Alleles } \\
\hline $\mathrm{G}$ & $140(86.4)$ & $115(71.0)$ & 1 (Reference) & \\
\hline $\mathrm{C}$ & $22(13.6)$ & $47(29.0)$ & $2.60(1.48-4.57)$ & $0.0006^{\mathrm{b}}$ \\
\hline$A L A D 1(\mathrm{GG})$ & $64(79.0)$ & $46(56.8)$ & 1 (Reference) & \\
\hline$A L A D 2(\mathrm{GC}, \mathrm{CC})$ & $17(21.0)$ & $35(43.2)$ & $2.86(1.43-5.72)$ & $0.002^{\mathrm{b}}$ \\
\hline
\end{tabular}

${ }^{\mathrm{a}} \chi^{2}$ test; ${ }^{\mathrm{b}} \mathrm{P}<0.05$. OR, odds ratio; $\mathrm{CI}$, confidence interval.

gender $(\mathrm{P}=0.89)$ in the control when compared to the primary brain tumor patients. The demographic data for the study groups are shown in Table I.

Types of primary adult brain tumor. Of the 81 patients with primary brain tumor, there were $31(38.3 \%)$ patients with meningioma, 41 (50.6\%) with glioma and 9 (11.1\%) with other tumors. ANOVA test revealed no statistically significant difference between the three types $(\mathrm{F}=0.184, \mathrm{P}=0.83)$ (Table II).

Genotypes and allele frequencies of ALAD G177C gene in the studied groups. The genotype frequencies of $A L A D \mathrm{G} 177 \mathrm{C}$ conformed to the Hardy-Weinberg equilibrium in the cases and controls. In patients with primary brain tumor, the frequencies of GG (ALAD1-1), GC (ALAD1-2) and CC (ALAD2-2) genotypes were $56.8,28.4$ and $14.8 \%$, respectively; and in controls, the frequencies were $79.0,14.8$ and $6.2 \%$, respectively. The frequencies of $\mathrm{G}$ and $\mathrm{C}$ alleles in primary brain tumor patients were 71 and 29\%; and in controls were 86.4 and $13.6 \%$, respectively. With regards to the risk of primary brain tumor development, using the GG genotype and G-wild allele as references, there was an increased risk of primary brain tumor with the GC (ALAD1-2) genotype (OR, 2.28, 95\% CI, 1.04-4.97 and $\mathrm{P}=0.03)$ and the $\mathrm{C}$ allele $(\mathrm{OR}, 2.60,95 \% \mathrm{CI}, 1.48-4.57$ and $\mathrm{P}=0.0006)$. There was a significant association between the brain tumor and the $A L A D 2$ (GC and CC) genotypes (OR, 2.86, 95\% CI, 1.43-5.72, and $\mathrm{P}=0.002$ ) (Table III).

Genotype frequencies of the ALAD G177C gene in the primary brain tumor sub-types. The genotype frequency of ALAD2 (GC and CC) was significantly higher in the meningioma patients $(\mathrm{P}=0.0004$; OR, 4.57; 95\% CI, 1.88-11.09), 
Table IV. Genotype frequencies of the $A L A D$ G177C gene in the primary brain tumor sub-types.

\begin{tabular}{|c|c|c|c|c|c|c|c|c|c|c|}
\hline \multirow[b]{3}{*}{$\begin{array}{l}A L A D \mathrm{G} 177 \mathrm{C} \\
\text { polymorphism }\end{array}$} & \multicolumn{10}{|c|}{ Primary brain tumor } \\
\hline & \multirow{2}{*}{$\begin{array}{c}\text { Controls } \\
\text { Patients, } \\
\text { no. }(\%)\end{array}$} & \multicolumn{3}{|c|}{ Glioma, $\mathrm{n}=41$} & \multicolumn{3}{|c|}{ Meningioma, $\mathrm{n}=31$} & \multicolumn{3}{|c|}{ Others, $n=9$} \\
\hline & & $\begin{array}{l}\text { Patients, } \\
\text { no. }(\%)\end{array}$ & $\begin{array}{c}\text { OR } \\
(95 \% \mathrm{CI})\end{array}$ & P-value & $\begin{array}{c}\text { Patients, } \\
\text { no. }(\%)\end{array}$ & $\begin{array}{c}\text { OR } \\
(95 \% \mathrm{CI})\end{array}$ & P-value ${ }^{a}$ & $\begin{array}{c}\text { Patients, } \\
\text { no. }(\%)\end{array}$ & $\begin{array}{c}\text { OR } \\
(95 \% \mathrm{CI})\end{array}$ & P-value \\
\hline $\begin{array}{l}\text { ALADI } \\
\text { (GG) }\end{array}$ & $64(79.0)$ & $26(63.4)$ & $\begin{array}{c}2.17 \\
(0.95-4.98)\end{array}$ & 0.08 & $14(45.2)$ & $\begin{array}{c}4.57 \\
(1.88-11.09)\end{array}$ & $0.0004^{\mathrm{b}}$ & $6(66.7)$ & $\begin{array}{c}1.88 \\
(0.43-8.31)\end{array}$ & 0.41 \\
\hline $\begin{array}{l}A L A D 2 \\
(\mathrm{GC}, \mathrm{CC})\end{array}$ & $17(21.0)$ & 15 (36.6) & & & $17(54.8)$ & & & $3(33.3)$ & & \\
\hline
\end{tabular}

${ }^{\mathrm{a}} \chi^{2}$ test; ${ }^{\mathrm{b}}<0.05$. OR; odds ratio; CI, confidence interval.

Table V. Blood lead level in primary brain tumor patients and controls.

\begin{tabular}{lccr}
\hline Parameters & Control group & Primary brain tumor patients & P-value \\
\hline Blood lead level, mean $\mu \mathrm{g} / \mathrm{dl} \pm \mathrm{SD}($ range $)$ & $25.02 \pm 12.65(4.5-39.0)$ & $28.61 \pm 13.23(4.4-62.0)$ & $0.08^{\mathrm{a}}$ \\
\hline
\end{tabular}

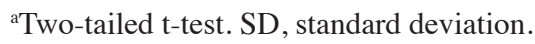

Table VI. Mean blood lead level in the different subtypes of primary brain tumor patients.

\begin{tabular}{lcccr}
\hline Parameters & Glioma & Meningioma & Other tumors & P-value \\
\hline Blood lead level, mean $\mu \mathrm{g} / \mathrm{dl} \pm \mathrm{SD}$ & $28.86 \pm 20.12$ & $29.37 \pm 14.35$ & $24.44 \pm 15.97$ & $0.76^{\mathrm{a}}$ \\
\hline
\end{tabular}

${ }^{\mathrm{a} A n a l y s i s ~ o f ~ v a r i a n c e ~ t e s t ~ b e t w e e n ~ t h r e e ~ t u m o r ~ t y p e s . ~ S D, ~ s t a n d a r d ~ d e v i a t i o n . ~}$

however, there was no significance with regards to the glioma patients $(\mathrm{P}=0.08$; OR, 2.17; 95\% CI, 0.95-4.98) and the other tumor patients $(\mathrm{P}=0.41$; OR, 1.88 ; 95\% CI, 0.43-8.31). The comparison of glioma and meningioma revealed no significant difference between them $(\mathrm{P}=0.12$; OR, 0.47; 95\% CI, 0.18-1.23) (Table IV).

Blood lead levels and primary brain tumor risk. In the control group, blood lead levels ranged from 4.5 to $39.0 \mu \mathrm{g} / \mathrm{dl}$ with a mean $\pm \mathrm{SD}$ of $25.02 \pm 12.65 \mu \mathrm{g} / \mathrm{dl}$ and in the brain tumor group, blood lead levels ranged from 4.4 to $62.0 \mu \mathrm{g} / \mathrm{dl}$ with a mean $\pm \mathrm{SD}$ of $28.61 \pm 13.23 \mu \mathrm{g} / \mathrm{dl}$, however, there was no significant difference $(\mathrm{P}=0.08)$ (Table $\mathrm{V})$.

The blood lead levels of primary brain tumor patients following stratification by the tumor types revealed that the mean lead level of glioma patients was $28.86 \pm 20.12 \mu \mathrm{g} / \mathrm{dl}$, meningioma was $29.37 \pm 14.35 \mu \mathrm{g} / \mathrm{dl}$ and in other tumors was $24.44 \pm 15.97 \mu \mathrm{g} / \mathrm{dl}$ with no statistically significant difference between the three types $(\mathrm{F}=0.28, \mathrm{P}=0.76$; ANOVA) (Table VI).

When blood lead was categorized by the levels $<10,10-30$ and $>30 \mu \mathrm{g} / \mathrm{dl}$, the number of subjects with blood lead level $<10,10-30,>30 \mu \mathrm{g} / \mathrm{dl}$ exhibiting the GG (ALADI-1) genotype was $37(33.6 \%), 36(32.8 \%)$ and 37 (33.6\%), the GC (ALADl-2) genotype was $7(20.1 \%), 6(17.1 \%)$ and $22(62.9 \%)$, and the CC (ALAD2-2) genotype was $1(5.9 \%), 3(17.6 \%)$ and $13(76.5 \%)$, respectively, with a significant difference $(\mathrm{P}=0.001)$. The number of subjects with blood lead level $<10,10-30$ and $>30 \mu \mathrm{g} / \mathrm{dl}$ exhibiting ALADI (GG) was 37 (33.6\%), 36 (32.8\%) and 37 (33.6\%) and those exhibiting ALAD2 (GC and CC) was $8(15.4 \%), 9(17.3 \%)$ and $35(67.3 \%)$, respectively, with a significant difference between $A L A D 2$ and $A L A D 1$ ( $\mathrm{P}=0.0002)$. $A L A D 1$ participants had a lead level with a mean value $\pm \mathrm{SD}$ of $25.93 \pm 12.73$ and $A L A D 234.39 \pm 17.87 \mu \mathrm{g} / \mathrm{dl}$, which indicates a significant increase in $A L A D 2$ when compared with $A L A D I(\mathrm{P}=0.0007)$ (Tables VII and VIII).

\section{Discussion}

Aside from a small percentage of brain tumors that can be explained by familial syndromes or exposure to ionizing radiation, extremely little is known regarding the etiology of brain tumors (17). Exposure to lead can result in significant adverse health effects to multiple organ systems. As the $A L A D$ G177C polymorphism affects the toxicokinetics of lead in the body and as exposure to lead may increase the risk of adult brain tumors, we hypothesized a possible association of the $A L A D$ G177C genotype and the risk of brain tumors in human (3). 
Table VII. Blood lead level in different genotype of studied groups.

\begin{tabular}{|c|c|c|c|c|}
\hline \multirow[b]{2}{*}{$A L A D$ genotype } & \multicolumn{3}{|c|}{ Blood lead level, $\mu \mathrm{g} / \mathrm{dl}$} & \multirow[b]{2}{*}{ P-value } \\
\hline & $<10$, no. $(\%)$ & $10-30$, no. $(\%)$ & $>30$, no. $(\%)$ & \\
\hline GG $(A L A D 1-1)$ & $37(33.6)$ & $36(32.8)$ & $37(33.6)$ & \\
\hline $\mathrm{GC}(A L A D 1-2)$ & $7(20.1)$ & $6(17.1)$ & $22(62.9)$ & \\
\hline $\mathrm{CC}(A L A D 2-2)$ & $1(5.9)$ & $3(17.6)$ & $13(76.5)$ & $0.001^{\mathrm{b}}$ \\
\hline$A L A D 1(\mathrm{GG})$ & $37(33.6)$ & $36(32.8)$ & $37(33.6)$ & \\
\hline$A L A D 2(\mathrm{GC}, \mathrm{CC})$ & $8(15.4)$ & $9(17.3)$ & $35(67.3)$ & $0.0002^{\mathrm{b}}$ \\
\hline
\end{tabular}

${ }^{\mathrm{a}} \chi^{2}$ test; ${ }^{\mathrm{b}} \mathrm{P}<0.05$. Percentages were calculated within the genotype.

Table VIII. Mean blood lead level in the ALAD1 and ALAD2 genotypes.

\begin{tabular}{lccc}
\hline Parameters & ALADl (GG) & ALAD2 (GC,CC) & P-value \\
\hline $\begin{array}{l}\text { Blood lead level, } \\
\text { mean } \mu \mathrm{g} / \mathrm{dl} \pm \mathrm{SD}\end{array}$ & $25.93 \pm 12.73$ & $34.39 \pm 17.87$ & $0.0007^{\mathrm{b}}$ \\
\hline
\end{tabular}

${ }^{\mathrm{a}}$ Two-tailed t-test; ${ }^{\mathrm{b}} \mathrm{P}<0.05$. SD, standard deviation.

In the present study, the frequencies of $A L A D 1$ and $A L A D 2$ were 79 and $21 \%$, respectively, this was similar to other studies which identified that the ALAD2 allele frequency ranges from 6 to $20 \%$ in Caucasian populations, with $\sim 18 \%$ of the Caucasian population being ALAD1-2 heterozygotes and 2\% being 2-2 homozygotes (18). In comparison, the $A L A D 2$ frequency was 3 to $11 \%$ in Asian populations and $3 \%$ in African-American populations (19-21).

The genotyping of the $A L A D$ G177C polymorphism in the present study declared a significant association between $A L A D 2$ and brain tumors. Following stratification of the patients with tumor type, there was a significant association between $A L A D 2$ and meningioma but not with glioma or other brain tumors; a result that corresponds with the results of Rajaraman et al 2006 (14,22).

The increased risk of meningioma in individuals with the $A L A D 2$ allele and the effect being dependent upon exogenous chemical exposures acting on the heme synthesis pathway or being independent of such exposures remains unknown. A direct effect of the $A L A D 2$ polymorphism may be indicated when the $A L A D 2$ allele has lower enzyme activity compared with the $A L A D 1$ allele, as the precursor ALA is believed to be neurotoxic and genotoxic (23). It is also possible that the increased risk of meningioma in $A L A D 2$ individuals occurs in the presence of chemicals that influence the heme synthesis pathway.

Several chemicals inhibit ALAD enzyme activity, including lead, trichloroethylene, bromobenzene and styrene (8). Additionally, Montenegro et al (24) and Fujihara et al (25) suggested that the significant inter-ethnic differences in the distribution of $A L A D$ G177C variants may help us to understand the inter-ethnic disparities in susceptibility to lead toxicity and brain tumors.
The meta-analysis conducted by Scinicariello et al (26) concluded that $A L A D 2$ carriers generally exhibit higher blood lead levels in adults at increased levels of lead exposure compared to the $A L A D 1$ carriers, and the strength of this analysis is based on the aggregation of published studies.

The present study observation of the increased risk with the $A L A D 2$ variant for meningioma, but not for glioma or other types, parallels with the observation of Lacourt et al (27) who confirmed the lack of association between glioma tumors and occupational exposure to selected combustion products, dusts and other chemical agents. The only strongly established risk factors for glioma are rare (ionizing radiation and rare medical conditions), possibly rarer compared to the agents that were examined in the present study.

The results of the present study showed that participants with $A L A D 2$ have a high blood lead level when compared with $A L A D 1$ in the case and control groups. This was in agreement with the results of Ziemsen et al (28), Steenland and Boffetta (6), Fleming et al (29) and Wetmur et al (30). All these studies examined populations with exposure levels that were higher compared to the normal level, with blood lead levels often $>30 \mu \mathrm{g} / \mathrm{dl}$, which was previously designated as a cut-off used as evidence of lead poisoning. These findings led to the suggestion that $A L A D 2$ may be a determinant of increased susceptibility to lead toxicity.

Hypotheses generated to support these results were based on the fact that ALAD2 codes for a more electronegative enzyme, and the ALAD2 protein is believed to be able to bind positively charged lead ion more tightly compared to the ALAD1 protein. Exposure to lead in carriers of the ALAD2 allele may be retained in their blood and tissues longer, increasing the chance of an adverse effect due to the presence of lead, which may initiate oxidative damage and cellular component structural changes, or due to inhibition of ALAD and the consequent accumulation of ALA (31).

From these initial studies, we conclude that the kinetics of lead in blood are modified by the $A L A D$ genotype, although perhaps only at relatively high levels of exposure. Shaik and Jamil (32) reported that blood lead levels did not differ significantly among $A L A D 1-1,1-2$ and 2-2 genotypes. Additionally, Sobin et al (33) reported that there was no association between $A L A D 2$ and sub-clinical blood lead burden.

One explanation for this may be the relatively low number of children with homozygous versus heterozygous for the 
polymorphism. A second explanation may be that the impact of the $A L A D 2$ polymorphism is highly variable in cases of lowest level lead exposure.

Süzen et al (34) and Yang et al (35) concluded that ALAD1-1 individuals may have a higher blood lead level compared to those with the ALAD1-2 genotype.

The present study has a number of strengths. It proved that the ALAD G177C polymorphism may modify the lead kinetics in the blood, is associated with higher blood lead burden and may provide a biomarker of neurotoxic risk. However, the potential bias could be minimized by restriction of inclusion criteria to patients, as confirmed by MRI and histopathology. The homogenous ethnic cohort limited the confounding genetic factors caused by ethnic heterogeneity.

\section{References}

1. Agency for Toxic Substances and Disease Registry (ATSDR): Toxicological profile for lead. U.S. Department of Health and Human Services, Atlanta, GA, USA 1999.

2. IARC WG: IARC monographs on the evaluation of carcinogenic risks to humans: inorganic and organic lead compounds. Vol. 87. World Health Organization, Lyon, France, 2006.

3. van Wijngaarden E and Dosemeci M: Brain cancer mortality and potential occupational exposure to lead: Findings from the National Longitudinal Mortality Study, 1979-1989. Int J Cancer 119: 1136-1144, 2006.

4. Navas-Acién A, Pollán M, Gustavsson P and Plato N: Occupation, exposure to chemicals and risk of gliomas and meningiomas in Sweden. Am J Ind Med 42: 214-227, 2002.

5. Cocco P, Heineman EF and Dosemeci M: Occupational risk factors for cancer of the central nervous system (CNS) among US women. Am J Ind Med 36: 70-74, 1999.

6. Steenland K and Boffetta P: Lead and cancer in humans: Where are we now? Am J Ind Med 38: 295-299, 2000.

7. Battistuzzi G, Petrucci R, Silvagni L, Urbani FR and Caiola S: delta-Aminolevulinate dehydrase: A new genetic polymorphism in man. Ann Hum Genet 45: 223-229, 1981.

8. Fujita H, Nishitani C and Ogawa K: Lead, chemical porphyria, and heme as a biological mediator. Tohoku J Exp Med 196: 53-64, 2002.

9. Shen XM, Wu SH, Yan CH, Zhao W, Ao LM, Zhang YW, He JM, Ying JM, Li RQ, Wu SM, et al: Delta-aminolevulinate dehydratase polymorphism and blood lead levels in Chinese children. Environ Res 85: 185-190, 2001.

10. Klaassen CD: Heavy metals and heavy-metal antagonists. In: Goodman \& Gilman's the pharmacological basis of therapeutics. Brunton LL, Lazo JS and Parker KL (eds). McGraw Hill, New York, NY, pp 1753-1775, 2006.

11. Villayandre BM, Paniagua MA, Fernández-López A and Calvo P: Effect of delta-aminolevulinic acid treatment on $N$-methyl-D-aspartate receptor at different ages in the rat brain. Brain Res 1061: 80-87, 2005

12. Bellinger D, Hu H, Titlebaum L and Needleman HL: Attentional correlates of dentin and bone lead levels in adolescents. Arch Environ Health 49: 98-105, 1994.

13. Chia SE, Huijun Z, Theng TM and Yap E: Possibilities of newer ALAD polymorphism influencing human susceptibility to effects of inorganic lead on the neurobehavioral functions. Neurotoxicology 28: 312-317, 2007.

14. Rajaraman P, Schwartz BS, Rothman N, Yeager M, Fine HA, Shapiro WR, Selker RG, Black PM and Inskip PD: Delta-aminolevulinic acid dehydratase polymorphism and risk of brain tumors in adults. Environ Health Perspect 113: 1209-1211, 2005.

15. Lee BK, Lee GS, Stewart WF, Ahn KD, Simon D, Kelsey KT, Todd AC and Schwartz BS: Associations of blood pressure and hypertension with lead dose measures and polymorphisms in the vitamin $\mathrm{D}$ receptor and $\delta$-aminolevulinic acid dehydratase genes. Environ Health Perspect 109: 383-389, 2001.

16. Miller DT, Paschal DC, Gunter EW, Stroud PE and D'Angelo J: Determination of lead in blood using electrothermal atomisation atomic absorption spectrometry with a L'vov platform and matrix modifier. Analyst (Lond) 112: 1701-1704, 1987.
17. Wrensch M, Minn Y, Chew T, Bondy M and Berger MS: Epidemiology of primary brain tumors: Current concepts and review of the literature. Neuro Oncol 4: 278-299, 2002.

18. Benkmann HG, Bogdanski P and Goedde HW: Polymorphism of $\delta$-aminolevulinic acid dehydratase in various populations. Hum Hered 33: 62-64, 1983

19. Hsieh LL, Liou SH, Chen YH, Tsai LC, Yang T and Wu TN: Association between aminolevulinate dehydrogenase genotype and blood lead levels in Taiwan. J Occup Environ Med 42: $151-155,2000$.

20. Kelada SN, Shelton E, Kaufmann RB and Khoury MJ: Delta-aminolevulinic acid dehydratase genotype and lead toxicity: A HuGE review. Am J Epidemiol 154: 1-13, 2001.

21. Miyaki K, Lwin H, Masaki K, Song Y, Takahashi Y, Muramatsu M and Nakayama T: Association between a polymorphism of aminolevulinate dehydrogenase (ALAD) gene and blood lead levels in Japanese subjects. Int J Environ Res Public Health 6: 999-1009, 2009.

22. Rajaraman P, Stewart PA, Samet JM, Schwartz BS, Linet MS, Zahm SH, Rothman N, Yeager M, Fine HA, Black PM, et al: Lead, genetic susceptibility, and risk of adult brain tumors. Cancer Epidemiol Biomarkers Prev 15: 2514-2520, 2006.

23. Silbergeld EK: Facilitative mechanisms of lead as a carcinogen. Mutat Res 533: 121-133, 2003.

24. Montenegro MF, Barbosa F Jr, Sandrim VC, Gerlach RF and Tanus-Santos JE: Ethnicity affects the distribution of delta-aminolevulinic acid dehydratase (ALAD) genetic variants. Clin Chim Acta 367: 192-195, 2006.

25. Fujihara J, Agusa T, Yasuda T, Soejima M, Kato H, Panduro A, Koda Y, Kimura-Kataoka K and Takeshita H: Ethnic variation in genotype frequencies of delta-aminolevulinic acid dehydratase (ALAD). Toxicol Lett 191: 236-239, 2009.

26. Scinicariello F, Murray HE, Moffett DB, Abadin HG, Sexton MJ and Fowler BA: Lead and delta-aminolevulinic acid dehydratase polymorphism: Where does it lead? A meta-analysis. Environ Health Perspect 115: 35-41, 2007.

27. Lacourt A, Cardis E, Pintos J, Richardson L, Kincl L, Benke G, Fleming S, Hours M, Krewski D, McLean D, et al: INTEROCC case-control study: Lack of association between glioma tumors and occupational exposure to selected combustion products, dusts and other chemical agents. BMC Public Health 13: 340-351, 2013.

28. Ziemsen B, Angerer J, Lehnert G, Benkmann HG and Goedde HW: Polymorphism of $\delta$-aminolevulinic acid dehydratase in lead-exposed workers. Int Arch Occup Environ Health 58: 245-247, 1986.

29. Fleming DE, Chettle DR, Wetmur JG, Desnick RJ, Robin JP, Boulay D, Richard NS, Gordon CL and Webber CE: Effect of the delta-aminolevulinate dehydratase polymorphism on the accumulation of lead in bone and blood in lead smelter workers. Environ Res 77: 49-61, 1998.

30. Wetmur JG, Kaya AH, Plewinska M and Desnick RJ: Molecular characterization of the human $\delta$-aminolevulinate dehydratase 2 (ALAD2) allele: Implications for molecular screening of individuals for genetic susceptibility to lead poisoning. Am J Hum Genet 49: 757-763, 1991.

31. Mahaffey K, McKinney J and Reigart JR: Lead and compounds. In: Environmental toxicants, human exposures and their health effects. 2nd edition. Lippmann M (ed). John Wiley and Sons, Inc, New York, NY, pp 481-521, 2000.

32. Shaik AP and Jamil K: A study on the ALAD gene polymorphisms associated with lead exposure. Toxicol Ind Health 24: 501-506, 2008.

33. Sobin C, Gutierrez M and Alterio H: Polymorphisms of delta-aminolevulinic acid dehydratase (ALAD) and peptide transporter 2 (PEPT2) genes in children with low-level lead exposure. Neurotoxicology 30: 881-887, 2009.

34. Süzen HS, Duydu Y, Aydin A, Ișimer A and Vural N: Influence of the delta-aminolevulinic acid dehydratase (ALAD) polymorphism on biomarkers of lead exposure in Turkish storage battery manufacturing workers. Am J Ind Med 43: 165-171, 2003.

35. Yang Y, Wu J and Sun P: Effects of delta-aminolevulinic acid dehydratase polymorphisms on susceptibility to lead in Han subjects from southwestern China. Int J Environ Res Public Health 9: 2326-2338, 2012. 